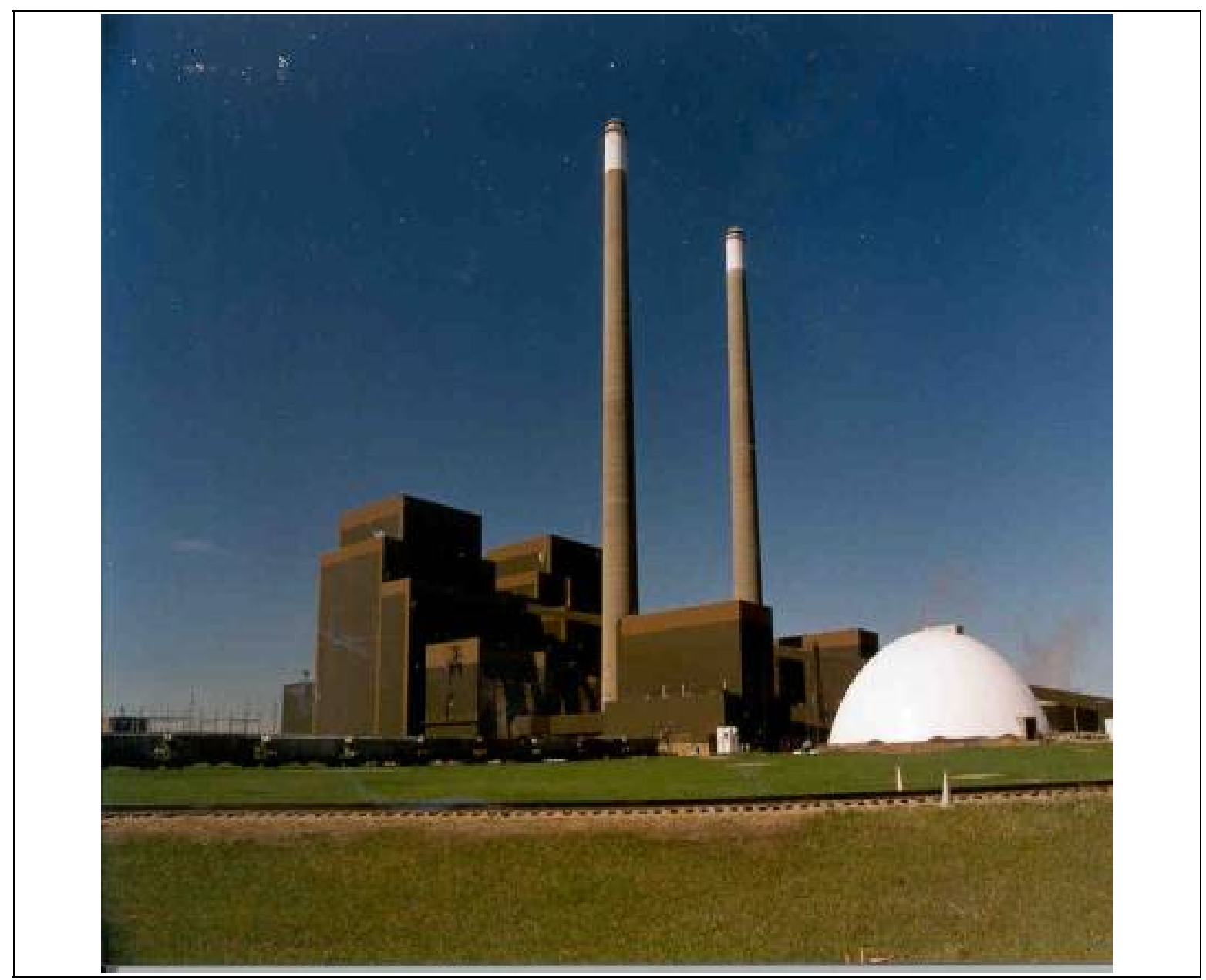

\title{
Lignite Fuel Enhancement
}

\section{Quarterly Technical Progress Report:} Period: January 1st, 2006 to March 31st, 2006 DOE Award Number: DE-FC26-04NT41763

Date: April 3rd, 2006

\section{Reported by:}

Charles Bullinger, P.E.

Generation Engineering Consultant/Lignite Fuel Enhancement Project Manager Great River Energy - Coal Creek Station 2875 Third Street SW Underwood, North Dakota 58576-9659

Telephone: 701-442-7001 


\section{Lignite Fuel Enhancement}

\section{Disclaimer}

"This report was prepared as an account of work sponsored by an agency of the United States Government. Neither the United States Government nor any agency thereof, nor any of their employees, makes any warranty, express or implied, or assumes any legal liability or responsibility for the accuracy, completeness, or usefulness of any information, apparatus, product, or process disclosed, or represents that its use would not infringe privately owned rights. Reference herein to any specific commercial product, process, or service by trade name, trademark, manufacturer, or otherwise does not necessarily constitute or imply its endorsement, recommendation, or favoring by the United States Government or any agency thereof. The views and opinions of authors expressed herein do not necessarily state or reflect those of the United States Government or any agency thereof." 


\section{Abstract}

This 7th quarterly Technical Progress Report for the Lignite Fuel Enhancement Project summarizes activities from January $1^{\text {st }}$ through March 31 st of 2006 . It also summarizes the subsequent purchasing activity, dryer/process construction, and testing. 


\section{Acknowledgement}

The authors wish to acknowledge the contributions and support provided by various project managers: Dr. Sai Gollakota (DOE), Matt Coughlin (Barr) Dave Rian (Barr), John Wheeldon (EPRI), Tony Armor (EPRI) and Mark Ness (GRE). 


\section{Table of Contents}

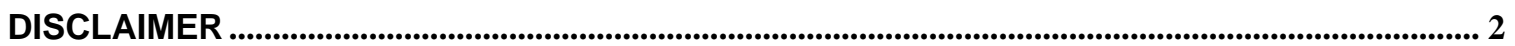

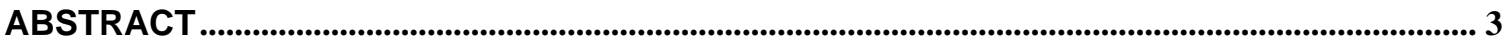

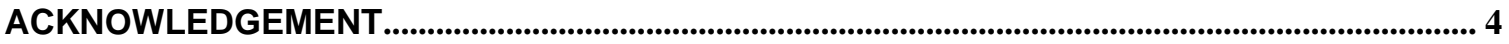

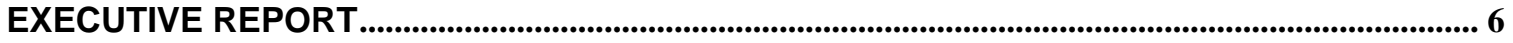

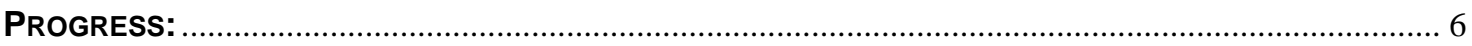

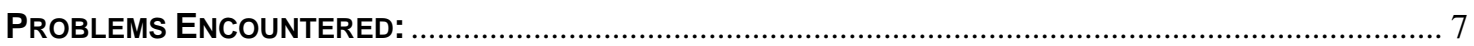

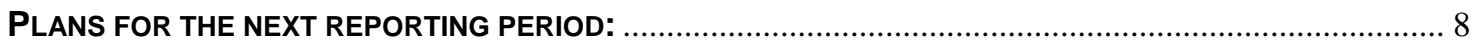

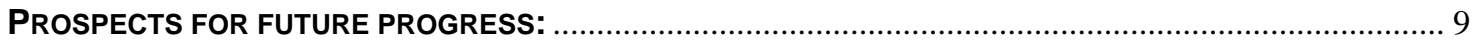

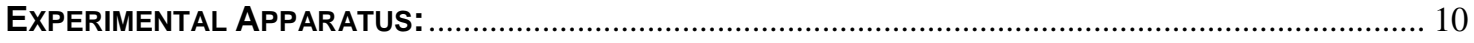

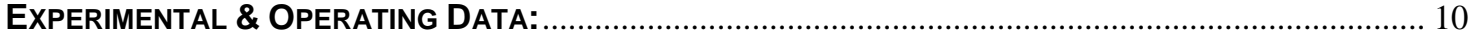

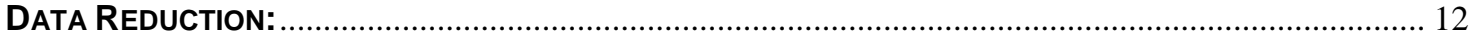

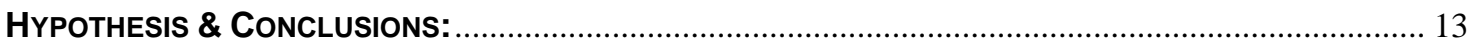




\section{Executive Report}

\section{Progress:}

The Design Team began conferencing again as construction completed and the testing program began. Primary focus this quarter was construction/installation completion. Phase 1 extension recommendation, and subsequent new project estimate, Forms 424 and 4600 were accepted by DOE headquarters. DOE will complete the application and amended contract.

All major mechanical equipment was run, checked out, and tested this quarter. All water, air, and coal flow loops were run and tested. The system was run on January $30^{\text {th }}$, shut down to adjust equipment timing in the control system on the $31^{\text {st }}$, and run to 75 ton//hour on February $1^{\text {st }}$. It ran for seven to eight hours per day until March $20^{\text {th }}$ when "pairs" testing ( 24 hour running) began. "Pairs" involves comparative testing of unit performance with seven "wet" pulverizers versus six "wet" and one "dry". During the interim, more operators were brought up to speed on system operation and control was shifted to the main Unit\#2 Control Room. The system is run now from the Unit control board operator and an equipment operator checks the system during regular rounds or when an alarm needs verification. The flawless start-up is unprecedented in the industry and credit should be made to the diligence and tenacity of Coal Creek maintenance/checkout staff.

Great River Energy and Headwaters did not meet to discuss the Commercialization Plan this quarter. The next meeting is pending data from the drying system. Discussions with Basin Electric, Otter Tail, and Dairyland continue and confidentiality secured as we promote dryers in their stations.

Lighting and fire protection were completed in January.

Invoices \#12 through \#20 are completed and forwarded following preliminary review and final DOE approval of additional project costs...Phase 1 extension and overrun request was approved by DOE headquarters as previously mentioned.

Charles Bullinger gave presentations at the EUCI: Clean Coal Conference in Denver and EPRI Program 75:Integrated Environmental Control and Program 66: Future Generation Options all in February. Over 50 people were in attendance at each session. EPRI has been making plans to "sunrise" a Dryer Interest Group in September of 2006. 


\section{Problems Encountered:}

Lehigh assignment agreement has been signed and negotiation of the Master Agreement was completed. No issues remain with Lehigh \& they have returned to the team. The drying systems main issues have been with the coal handling system not dryer or baghouse. Liewell pulley, bound air locks, and crusher throughput have all been issues although the dryer has performed and dried to 75 ton/hour in each case. 
Plans for the next reporting period:

"Pairs" testing will complete, data collected, and performance calculations reviewed for input to the commercialization recommendation. DOE project continuation application will have been completed and forwarded to the NETL. Preliminary performance report will be completed and reviewed. System capacity testing will have begun. Commercial estimate and any changes will have been completed. Preparation for recommendation to the Great River Energy Board of Directors for Phase 2 continuation will begin. 


\section{Prospects for future progress:}

The prospects are quite good that all the next Quarter deliverables will be met.

The expectation today, based on preliminary information, is that the project will continue to Phase 2. 


\section{Experimental Apparatus:}

Details of the dryer and system, P\&ID's, schematics, and drawings contain "Limited Rights" information which cannot be disclosed at this particular time.

\section{Experimental \& Operating Data:}

Construction phase completed. Shakedown and Start-up completed.

Dryer in operation: moisture leaving the drying system stack

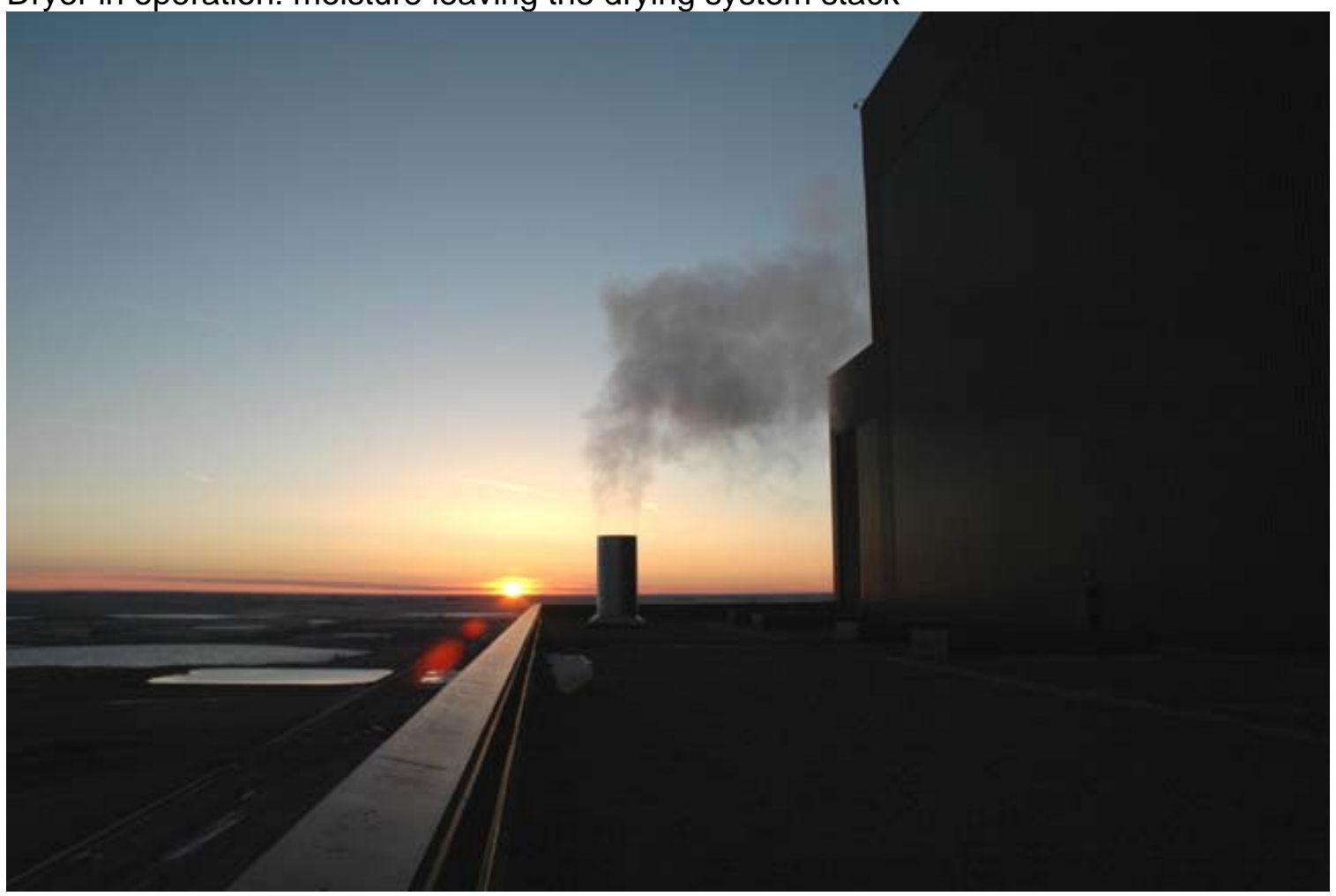




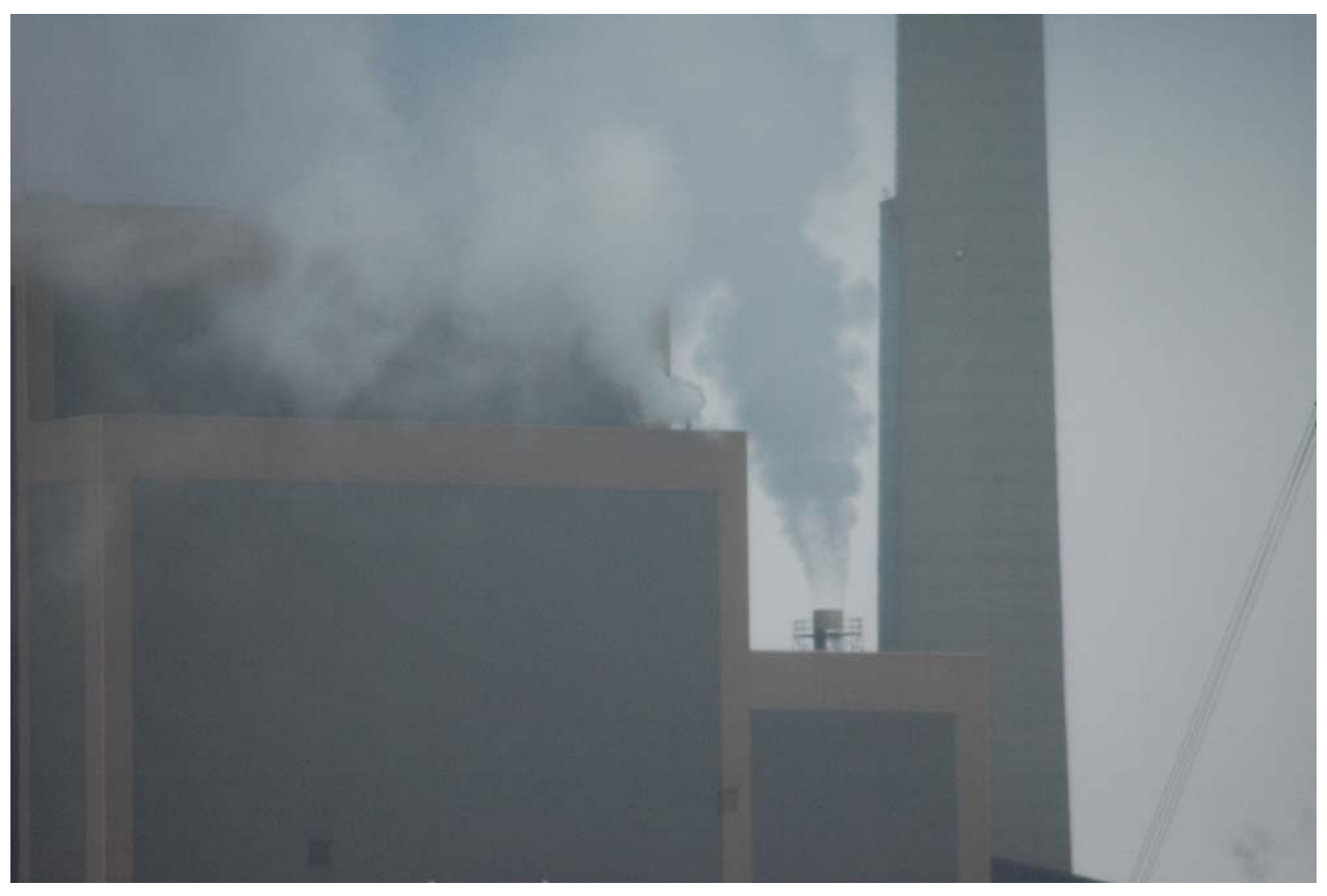

CD26 Feed Vs Product

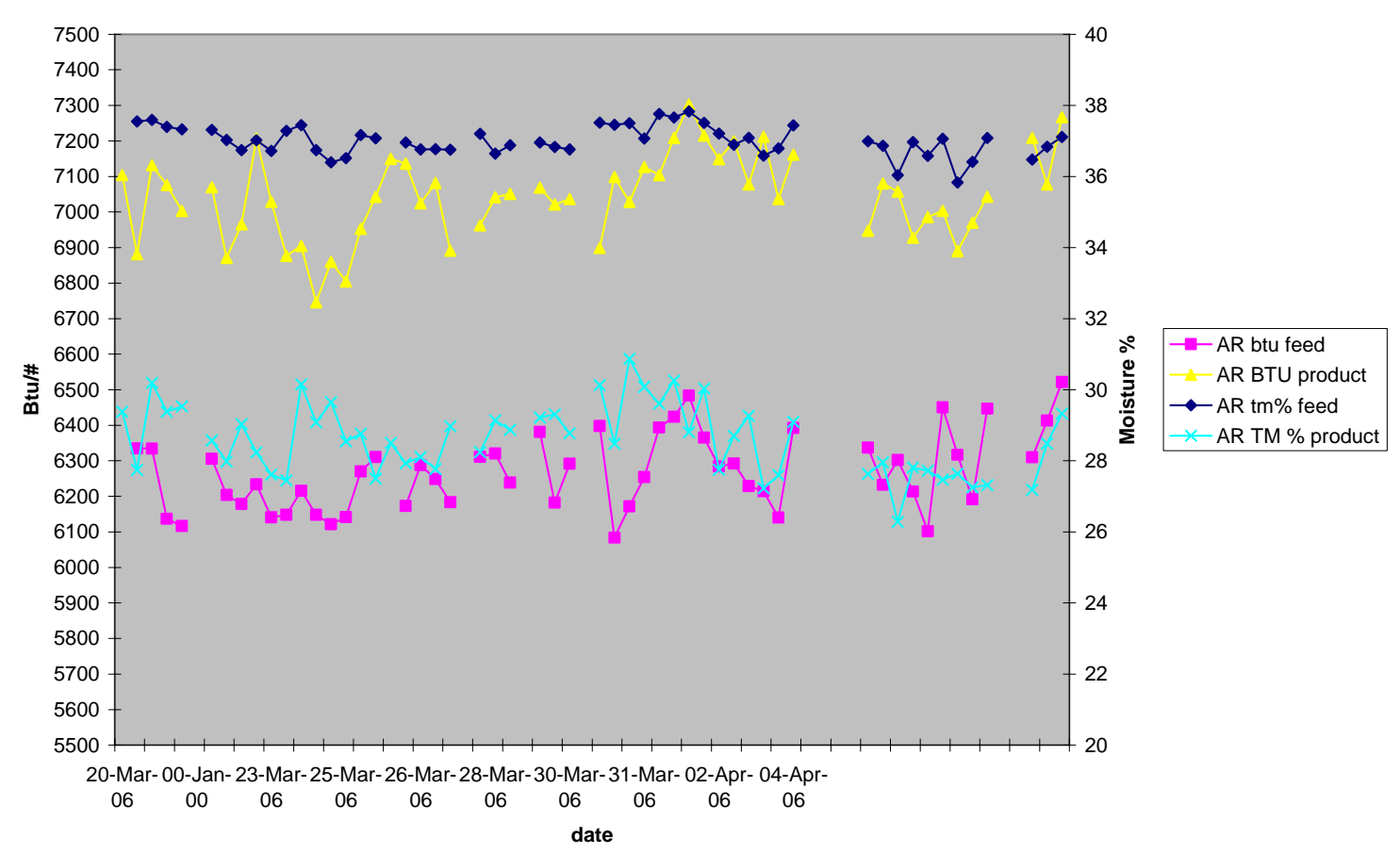

Data shows coal analysis, btu improvement and moisture reduction during the "pairs" testing completed thus far. 


\section{Data Reduction:}

\begin{tabular}{|c|c|c|c|c|c|}
\hline Parameter & Units & FBD I/S & $\begin{array}{l}\text { FBD } \\
\text { O/S }\end{array}$ & Change & Units \\
\hline Total Coal Flow Rate & $\mathrm{klbs} / \mathrm{hr}$ & 953 & 973 & -2.03 & $\%$ \\
\hline Stack Flow Rate & kscfm & 1,612 & 1,626 & -0.89 & $\%$ \\
\hline Pulverizer 26 Power & $\mathrm{kW}$ & 548 & 601 & -8.85 & $\%$ \\
\hline Total Pulverizer Power & $\mathrm{kW}$ & 4,057 & 4,206 & -3.53 & $\%$ \\
\hline NOx Mass Emissions & $\mathrm{lb} / \mathrm{hr}$ & 1,345 & 1,473 & -8.65 & $\%$ \\
\hline SOx Mass Emissions & $\mathrm{lb} / \mathrm{hr}$ & 3,635 & 3,714 & -2.14 & $\%$ \\
\hline $\begin{array}{l}\text { APH } 21 \text { Gas Exit } \\
\text { Temperature } \\
\text { APH } 22 \text { Gas Exit }\end{array}$ & Deg. F & 353 & 362 & -9 & Deg. F \\
\hline Temperature & Deg. F & 368 & 377 & -9 & Deg. $F$ \\
\hline Stack Temperature & Deg. F & 180 & 184 & -4 & Deg. F \\
\hline
\end{tabular}

First "pairs" performance comparison table showing the improvement (change) with seven pulverizers running Fluidized Bed Dryer (FBD) in or out of service. This data is preliminary as the "pairs" is not completed and on-going. 


\section{Hypothesis \& Conclusions:}

Hypothesis remains the same. We will be able to dry lignite an increment to benefit the performance of and reduce emissions from a coal burning electric power generating station. 